\title{
Laccases from Actinobacteria-What We Have and What to Expect
}

\author{
Tatiana Alves Rigamonte Fernandes ${ }^{1,2^{*}}$, Wendel Batista da Silveira2, \\ Flávia Maria Lopes Passos², Tiago Domingues Zucchi' ${ }^{1}$ \\ ${ }^{1}$ Embrapa Meio Ambiente, Rodovia SP 340, Jaguariúna, Brazil \\ ${ }^{2}$ Departamento de Microbiologia, BIOAGRO, Universidade Federal de Viçosa, Campus Universitário, \\ Viçosa, Brazil \\ Email: ${ }^{\text {tatiana.fernandes@embrapa.br }}$
}

Received 3 February 2014; revised 3 March 2014; accepted 23 March 2014

Copyright (C) 2014 by authors and Scientific Research Publishing Inc.

This work is licensed under the Creative Commons Attribution International License (CC BY).

http://creativecommons.org/licenses/by/4.0/

(c) $\underset{\mathrm{EY}}{\mathrm{E}}$ Open Access

\section{Abstract}

Laccases are blue multicopper enzymes, capable of oxidizing diverse aromatic and non-aromatic compounds of industrial interest, concomitantly with reduction of molecular oxygen to water. Tolerance to extreme conditions, such as high temperature, salinity or extreme $\mathrm{pH}$, is required for practical industrial applications. Here we focus on bacterial laccases from the phylum Actinobacteria, notably the order Actinomycetales. Currently, less than 10 enzymes have been properly characterized, all belonging to genus Streptomyces, but it is noteworthy that all of them have exhibited industrially important properties. Furthermore, studies with enzymes from this phylum revealed a novel molecular structure of laccases, providing the basis for a distinct family, the two-domain laccases. The relevant traits of actinomycetes laccases emphasize the need for more studies involving the isolation of this bacterial group from lignin-rich environmental samples, detection of their laccase activity and thereafter, characterization of the proteins and related genes. The nonhomogeneous responses of actinomycetes laccases to traditional inhibitors, substrates or metal ions have challenged the currently accepted "laccase concept". Finally, considering that distinguishing laccase activity in vitro from other ligninolytic enzymes becomes a difficult task due to overlaps in catalytical properties of the enzymes, we proposed a simple flow chart to help experimental assays.

\section{Keywords}

Actinomycetes, Lignin Degradation, Multicopper Oxidase, Laccases

${ }^{*}$ Corresponding author. 


\section{Introduction}

Laccases (benzenediol:oxygen oxidoreductases, EC 1.10.3.2) are blue multicopper oxidases, capable of oxidizing a broad range of aromatic and non-aromatic compounds [1]. These enzymes were first discovered in plants [2], thereafter in fungi [3], and only one century later they were found in Bacteria [4]. Most studies about laccases are still conducted on fungi [5], and few are known about the physiological roles of laccases in bacteria, their potential for industrial application or their biochemical properties.

The role of laccase-producing microorganisms on the environment is not thoroughly elucidated, but it is speculated that these organisms are involved in the degradation of recalcitrant (poly) phenolic compounds [6]. Interestingly, the oxidation of large molecules by laccase is directly inhibited by steric hindrance, but the reaction can still occur through chemical mediators-small molecules oxidized by laccases that diffuse in surrounding medium and oxidize the substrate [7]. This laccase-mediator system (LMS) also allows indirect oxidation of non-phenolic compounds [8] or even molecules with higher redox potentials than laccase. Besides this intrinsic versatility and the large substrate variety, application of laccases has been suggested for diverse industrial processes; however, few have been accomplished so far, due to high costs of microbial cultivation or enzyme purification [5].

In fungi, laccases have been extensively reviewed in many aspects: occurrence, characterization of genes and proteins from different taxonomic divisions, functions and applications [9]-[14]. Whereas the literature provides some general reviews on bacterial laccases [15] [16], and some studies have dealt with lignocellulolytic potential of actinomycetes [17] [18], its current laccase state-of-art is still obscure. It is remarkable that actinomycete strains are generally detected in prospective bacterial studies, and laccases with unusual properties have been discovered [19]-[21]. Here, we present a view of this interesting microbial group, its characterized laccases and the effects of its properties on the concept of laccase enzymes.

\section{Defining Laccase Enzymes}

\section{Laccase and Other Multicopper Oxidases}

Laccases are generally defined as multi-copper oxidase enzymes (MCO) that catalyse oxidation of diverse phenolic and non-phenolic substances using dioxygen as final electron acceptor, producing water molecules as byproduct, and that possess some conserved amino acid motifs responsible for binding to copper atoms [22]. However, advances in studies concerning the diverse group of multicopper oxidases (MCO) have raised a question about the classification of laccase, due to overlaps in amino acid signature and substrates are shared by many MCO; for instance, ascorbate oxidase, tyrosinase, polyphenol oxidase or bilirubin oxidase [23]. Thus, a narrow definition has not been achieved so far. Therefore, it has been proposed the use of the term "laccase-like multicopper oxidase" (LMCO) [24] for the formerly named laccase enzymes. This term has been adopted in this work for simplification.

\section{Actinobacteria and Their LMCO}

\subsection{The Phylum and Its Biotechnological Potential}

The phylum Actinobacteria represents one of the largest and most diverse groups within the Bacteria domain; it comprises Gram-positive bacteria with a high G + C mol\% content in DNA [25]. It is a cosmopolitan group which was found inhabiting almost all known ecological niches. Actinobacteria are considered of great importance in the process of degradation of recalcitrant and relatively complex polymers that are naturally found in litter and soil, such as lignin and humic acid [6] [26]-[29]. Particularly, the order Actinomycetales has attracted industrial attention mainly due to its outstanding capacity to produce compounds with high biotechnological values, e.g., antibiotics. Indeed, actinomycetes are considered remarkable antibiotic-producing and since their first antibiotic discovery (streptomycin at late 40's), their participation in the antibiotic market continues to grow [30] [31]. Similarly to these unique antibiotic biosynthetic pathways, it has been stated that actinomycetes may also produce attractive enzymes for biotechnological applications [32].

\subsection{Characterized LMCO from Actinomycetes}

Studies on LMCO characterization from actinobacteria are scarce and it is an open field for exploration. To the 
best of our knowledge, only LMCO from the following species have been characterized in gene and protein levels: Streptomyces griseus IFO 13350 [33], Streptomyces lavendulae REN-7 [34], Streptomyces cyaneus CECT 3335 [19], Streptomyces coelicolor M145 [35], Streptomyces psammoticus MTCC 7334 [20], Streptomyces ipomoea CECT 3341 [36], Streptomyces sviceus DMS 924 [21] and Streptomyces sp. C1 [37]. Their main properties are presented in Table 1. Many putative laccase genes are listed in data banks, and other LMCO have been characterized only in protein level; e.g., the thermotolerant LMCO from Streptomyces sp. SB086 [38].

\subsection{Structural Properties-Two-Domain LMCO}

LMCO belong to the group of blue multicopper proteins containing four copper atoms classified in types 1 to 3 (two atoms are type 3). All secondary structural elements typical of fungal LMCO are present in bacterial sequences [41]. The three Cu-binding domains that form the active site are composed by multiple histidine and one cysteine copper-binding residues, which are present in the type 1 ( 2 his +1 cys), 2 e 3 sites ( 8 his), where $\mathrm{Cu}$ atoms are distributed [33] [42] [43]. This canonical structure is also found among the characterized actinobacterial LMCO (Figure 1). Furthermore, studies on actinobacterial LMCO have provided a very interesting finding concerning to their molecular structure. Instead of three structural domains, some actinobacterial LMCO present only two domains (wherein the three $\mathrm{Cu}$-binding domains and the four $\mathrm{Cu}$ atoms are distributed). This peculiar two-domain structure, also named "small LMCO" was elucidated in Streptomyces coelicolor [35]. It lacks the second domain, which is composed by one loop at the end of domain one, two $\beta$-turns from domain three, and its own amino acid residues [42]. Two-domain LMCO has not been found in fungi so far, but was found in ten other phyla within Bacteria, and also in Archaea, by molecular analysis [44].

Table 1. Characterized laccases from Actinobacteria and their main properties.

\begin{tabular}{|c|c|c|c|c|c|c|c|}
\hline Laccase, species & $\begin{array}{l}\text { Secondary, } \\
\text { quaternary } \\
\text { structures }\end{array}$ & $\begin{array}{l}\text { Molecular } \\
\text { mass }\end{array}$ & $\begin{array}{l}\text { Optimum } \mathrm{pH} \\
\text { substrate }\end{array}$ & Kinetic parameters ${ }^{*}$ & $\begin{array}{l}\text { Optimum } \\
\text { temperature }\end{array}$ & $\begin{array}{l}\text { Tolerance/ } \\
\text { Resistance }\end{array}$ & Reference \\
\hline $\begin{array}{l}\text { EpoA, Streptomyces } \\
\text { griseus }\end{array}$ & $\begin{array}{l}2 \text { domains, } \\
\text { trimer }\end{array}$ & $\begin{array}{l}114 \mathrm{kDa} \text {, } \\
\text { (monomer: } \\
38 \mathrm{kDa} \text { ) }\end{array}$ & $\begin{array}{c}\text { 6.5, } \\
\text { DMPPDA }\end{array}$ & $\mathrm{K}_{\mathrm{m}}=0.42 \mathrm{mM}, \mathrm{V}_{\max }=0.85 \mathrm{nmol} / \mathrm{min}$ & $40^{\circ} \mathrm{C}$ & High temperature & [33] \\
\hline $\begin{array}{l}\text { STSL, Streptomyces } \\
\text { lavendulae }\end{array}$ & nd & $73 \mathrm{kDa}$ & 4.5, catechol & $\begin{aligned} & \mathrm{Km}= 0.043 \mathrm{mM}, \mathrm{k}_{\mathrm{cat}}=10.9 \mathrm{~s}^{-1} \\
& \mathrm{k}_{\mathrm{cat}} / \mathrm{K}_{\mathrm{m}}=253 \mathrm{mM}^{-1} \cdot \mathrm{s}^{-1}\end{aligned}$ & $50^{\circ} \mathrm{C}$ & $\begin{array}{l}\text { Alkaline medium, } \\
\text { high temperature }\end{array}$ & [34] \\
\hline $\begin{array}{l}\mathrm{Nd}, \text { Streptomyces } \\
\text { cyaneus }\end{array}$ & nd & $75 \mathrm{kDa}$ & 4.5, ABTS & $\mathrm{Km}=0.38 \mathrm{mM}$ & $70^{\circ} \mathrm{C}$ & High temperature & [19] \\
\hline $\begin{array}{l}\text { SLAC, Streptomyces } \\
\text { coelicolor }\end{array}$ & $\begin{array}{l}2 \text { domains, } \\
\text { trimer }\end{array}$ & $\begin{array}{l}69 \mathrm{kDa} \text {; } \\
\text { (monomer: } \\
32 \mathrm{kDa} \text { ) }\end{array}$ & $\begin{array}{l}\text { 9.4, DMP } \\
4.0, \text { ABTS }\end{array}$ & $\begin{array}{c}\mathrm{Km}=0.4 \mathrm{mM}, \mathrm{k}_{\mathrm{cat}}=4 \mathrm{~s}^{-1} \\
\mathrm{k}_{\mathrm{cat}} / \mathrm{K}_{\mathrm{m}}=10 \mathrm{mM}^{-1} \cdot \mathrm{s}^{-1}\end{array}$ & $60^{\circ} \mathrm{C}$ & $\begin{array}{l}\text { Alkaline medium, } \\
\text { high temperature }\end{array}$ & $\begin{array}{c}{[35][39]} \\
{[40]}\end{array}$ \\
\hline $\begin{array}{l}\text { Nd, Streptomyces } \\
\text { psammoticus }\end{array}$ & nd & $43 \mathrm{kDa}$ & 8.5, ABTS & $\mathrm{K}_{\mathrm{m}}=0.39 \mathrm{mM}(\mathrm{ABTS}), \mathrm{K}_{\mathrm{m}}=3.35(\mathrm{SGZ})$ & $45^{\circ} \mathrm{C}$ & $\begin{array}{l}\text { High salt } \\
\text { concentration, } \\
\text { alkaline medium }\end{array}$ & {$[20]$} \\
\hline $\begin{array}{l}\text { SilA, Streptomyces } \\
\text { ipomoea }\end{array}$ & $\begin{array}{l}2 \text { domains, } \\
\text { dimer }\end{array}$ & $\begin{array}{l}79 \mathrm{kDa} \text {; } \\
\text { (monomer: } \\
44.7 \mathrm{kDa} \text { ) }\end{array}$ & $\begin{array}{l}\text { 5.0, ABTS; } 6.5 \text {, } \\
\text { aromatic amine; } \\
\text { 8.0, DMP }\end{array}$ & $\begin{aligned} & \mathrm{K}_{\mathrm{m}}= 0.40 \mathrm{mM}, \mathrm{V}_{\max }=7.59 \mathrm{mU} / \mu \mathrm{g}, \\
& \mathrm{k}_{\mathrm{cat}}=, 9.99 \mathrm{~s}^{-1}, \mathrm{k}_{\mathrm{cat}} / \mathrm{K}_{\mathrm{m}}=25 \mathrm{mM}^{-1} \cdot \mathrm{s}^{-1} \\
&(\mathrm{ABTS}) ; \mathrm{K}_{\mathrm{m}}=4.27 \mathrm{mM}, \\
& \mathrm{V}_{\max }=3.19 \mathrm{mU} / \mu \mathrm{g}, \mathrm{k}_{\mathrm{cat}}=4.20 \mathrm{~s}^{-1} \\
& \mathrm{k}_{\text {cat }} / \mathrm{K}_{\mathrm{m}}=0.98 \mathrm{mM}^{-1} \cdot \mathrm{s}^{-1}(\mathrm{DMP})\end{aligned}$ & $60^{\circ} \mathrm{C}$ & $\begin{array}{c}\text { High salt } \\
\text { concentration }\end{array}$ & [36] \\
\hline $\begin{array}{l}\text { Ssl1, Streptomyces } \\
\text { sviceus }\end{array}$ & $\begin{array}{l}2 \text { domains, } \\
\text { trimer }\end{array}$ & $\begin{array}{l}98.3 \mathrm{kDa} \text {; } \\
\text { (monomer, } \\
32.5 \mathrm{kDa} \text { ) }\end{array}$ & $\begin{array}{l}\text { 4.0, ABTS; } 8.0 \text {, } \\
\text { SGZ; 9.0, DMP } \\
\text { or guaiacol; }\end{array}$ & $\begin{array}{c}\mathrm{K}_{\mathrm{m}}=0.36 \mathrm{mM}, \mathrm{k}_{\mathrm{cat}}=7.38 \mathrm{~s}^{-1}(\mathrm{ABTS}) ; \\
\mathrm{K}_{\mathrm{m}}=0.89 \mathrm{mM}, \mathrm{k}_{\mathrm{cat}}=0.32 \mathrm{~s}^{-1}(\mathrm{DMP}) ; \\
\mathrm{K}_{\mathrm{m}}=15.8 \mathrm{mM}, \mathrm{k}_{\mathrm{cat}}=5.78 \times 10^{-2} \mathrm{~s}^{-1} \\
(\mathrm{SGZ})\end{array}$ & --- & $\begin{array}{l}\text { High temperature, } \\
\text { alkaline medium, } \\
\text { wide } \mathrm{pH} \text { variation }\end{array}$ & {$[21]$} \\
\hline $\begin{array}{c}\text { SCLAC, } \\
\text { Streptomyces sp. }\end{array}$ & 2 domains & $38 \mathrm{kDa}$ & $\begin{array}{l}\text { 8.0, ABTS or } \\
\text { guaiacol; } 7.0 \text {, } \\
\text { DMP }\end{array}$ & $\begin{array}{c}\mathrm{K}_{\mathrm{m}}=0.43 \mathrm{mM}, \mathrm{V}_{\max }=8.62 \mathrm{mU} / \mu \mathrm{gg}, \\
\mathrm{k}_{\mathrm{cat}}=8.45 \mathrm{~s}^{-1}, \mathrm{k}_{\mathrm{cat}} / \mathrm{K}_{\mathrm{m}}=17.6 \mathrm{mM}^{-1} \cdot \mathrm{s}^{-1} \\
(\mathrm{ABTS}) ; \mathrm{K}_{\mathrm{m}}=5.58 \mathrm{mM}, \\
\mathrm{V}_{\max }=3.45 \mathrm{mU} / \mu \mathrm{\mu g}, \mathrm{k}_{\mathrm{cat}}=4.88 \mathrm{~s}^{-1}, \\
\mathrm{k}_{\mathrm{cat}} / \mathrm{K}_{\mathrm{m}}=0.83 \mathrm{mM}{ }^{-1} \cdot \mathrm{s}^{-1}(\mathrm{SGZ}) ; \\
\mathrm{K}_{\mathrm{m}}=1.65 \mathrm{mM}, \mathrm{V}_{\max }=5.26 \mathrm{mU} / \mu \mathrm{g}, \\
\mathrm{k}_{\mathrm{cat}}=2.39 \mathrm{~s}^{-1}, \mathrm{k}_{\mathrm{cat}} / \mathrm{K}_{\mathrm{m}}=1.45 \mathrm{mM}{ }^{-1} \cdot \mathrm{s}^{-1} \\
\text { (guaiacol) }\end{array}$ & $40^{\circ} \mathrm{C}$ & $\begin{array}{l}\text { Alkaline medium, } \\
\text { high temperature }\end{array}$ & [37] \\
\hline
\end{tabular}

Abbreviations: ABTS, 2,2'-azino-bis(3-ethylbenzothiazoline-6-sulphonic acid); DMP, 2,6-dimethoxyphenol; DMPPDA, dimethyl p-phenylenediamine sulphate; SGZ, syringaldazine; nd, no available data. Except where indicated, parameters were determined at optimum pH and cited substrate. For SLAC, parameters were determined with DMP, at $\mathrm{pH} 9.4$. 


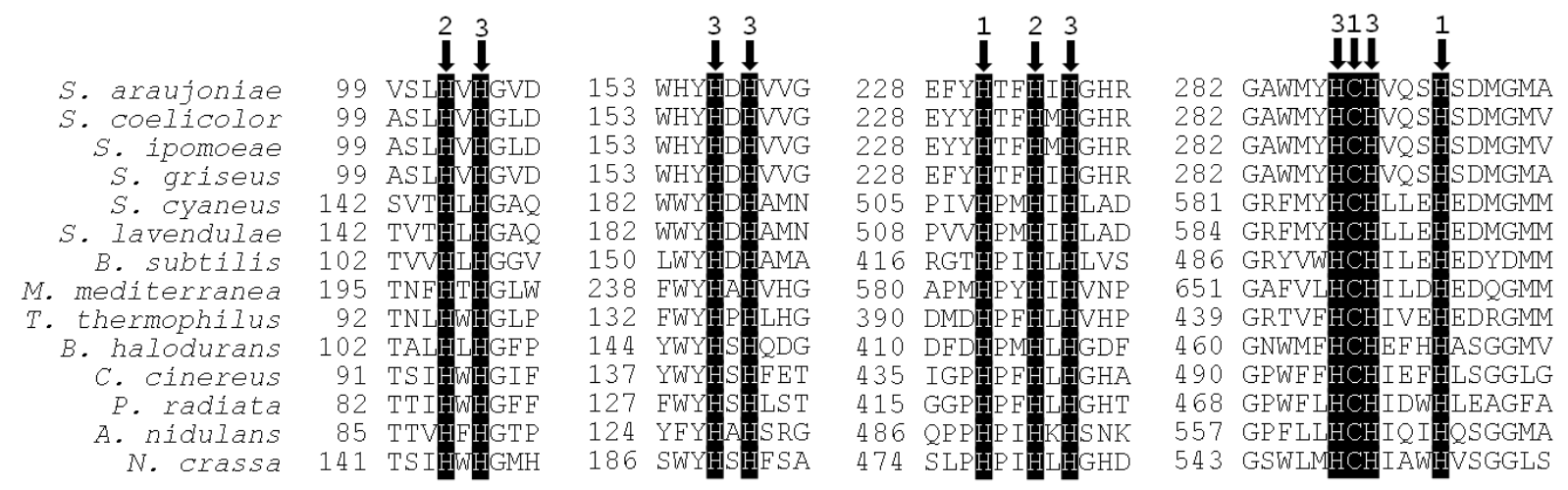

Figure 1. Alignment of Cu-binding domains of actinobacterial, bacterial and fungal laccases. Arrows and accompanying numbers indicate the amino acid residues for $\mathrm{Cu}$-binding and the type of each ligand $\mathrm{Cu}$. The position of the first residue of each fragment in the polypeptide chain is indicated. Streptomyces spp.: S. araujoniae (unpublished); S. coelicolor (CAB45586); S. ipomoea (ABH10611); S. griseus (BAB64332); S. cyaneus (ADX97492); S. lavendulae (BAC16804). Other bacteria: Bacillus subtilis (ADZ57284); Marinomonas mediterranea (AAF75831); Thermus thermophilus (BAE16261); Bacillus halodurans (AAP57087). Basidiomycota: Coprinus cinereus (ABP81837); Phlebia radiata (Q01679). Ascomycota: Aspergillus nidulans (Q96VT5); Neurospora crassa (AAA33592).

In silico studies have been performed by comparison of genomes with published gene sequences of characterized LMCO, generating thousands of putative LMCO genes that have broadened its distribution in the bacterial phyla. Searching within 2211 complete and draft bacterial genomes and four metagenomic data sets, Ausec et al. [44] have found 1240 genes for LMCO enzymes in 807 different microorganisms, or 36\% of all organisms evaluated. This high frequency changes the idea that LMCO are proteins found only in few bacteria [39].

Two-domain LMCO characterized in actinomycetes are active as dimers (S. ipomoea) or trimers (S. griseus, S. coelicolor and S. sviceus). The oligomerization in actinobacterial LMCO (Table 2) contrasts with fungal, which are mainly monomeric enzymes.

\section{Industrial Applications}

Lignin is the most associated substrate for LMCO oxidation, in which the enzyme acts on its polymerization as well as on depolymerization [10]. Lignin tightly involves cellulose fibers in wood and is very resistant to breakdown. It is generally viewed as a side-product of lignocelluloses treatment and used as thermal resource after wood physicochemical pre-treatments. Lignin comprises approximately $10 \%$ to $30 \%$ of vegetal dry mass [27] and therefore, achieving an efficient method for lignin-rich biomass conversion into second generation ethanol production may be economically advantageous.

Lignin structure is very complex, composed by randomly linked subunits. Two consequences of this structure are: a) only a few enzymes are able to cause cleavages-mainly manganese peroxidase, lignin peroxidase and LMCO; and b) these enzymes are flexible for acting on many different covalent linkages. The versatility and eco-friendly mechanism (water is released as byproduct) of LMCO have long attracted industry interest and currently their application is desired in diverse industrial processes. For instance, application of LMCO has been proposed for activities from many sectors of industry [7] [10] [45]-[48]:

- textile: elimination or attenuation of dyes, improvement in whiteness in conventional bleaching of cotton, use in cleansing products for cloth washing;

- food: elimination of undesirable phenolic compounds in bread, juices, beer and wine for stabilization and improvement of their organoleptic properties; consumption of oxygen in packed food or derived from plants to avoid undesired oxidation;

- pulp and paper: cellulose bleaching, cross-linking in ligninaceous compounds, decolorization and deinking of printed paper;

- pharmaceutical: functional organic compounds synthesis (e.g. anesthetics, antibiotics and anti-inflammatory), biosensor for detection of target molecules in immunoassays;

- nanobiotechnology: polymers production, use in biosensors for detection of oxygen and phenolic compounds, use as biocatalyst for the electrode reactions in medical applications; 
Table 2. Substrate specificity and inhibition profiles of characterized laccases from Actinobacteria.

\begin{tabular}{|c|c|c|c|c|c|c|c|c|c|c|}
\hline \multirow[b]{2}{*}{ Laccase, species } & \multicolumn{7}{|c|}{ Substrate } & \multicolumn{3}{|c|}{ Inhibition } \\
\hline & 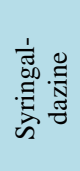 & 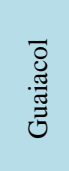 & $\stackrel{n}{\mathscr{Q}}$ & $\sum_{\Delta}^{0}$ & $\begin{array}{l}\nwarrow \\
0 \\
0\end{array}$ & 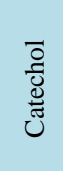 & 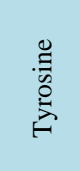 & 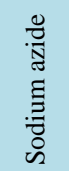 & 㫐 & References \\
\hline EpoA, Streptomyces griseus & No & Low & --- & No & Yes & No & No & Yes & Yes & [33] \\
\hline STSL, Streptomyces lavendulae & Yes & Low & --- & --- & Yes & Yes & $\begin{array}{l}\text { Very } \\
\text { weak }\end{array}$ & Yes & Yes & [34] \\
\hline Streptomyces cyaneus & Low & $\begin{array}{l}\text { Very } \\
\text { low }\end{array}$ & Yes & Yes & --- & --- & No & Yes & Yes & [19] \\
\hline SLAC, Streptomyces coelicolor & Yes & --- & Yes & Yes & Yes & Yes & -- & No & No & [35] [39] [40] \\
\hline Streptomyces psammoticus & Yes & Yes & Yes & Yes & Yes & Yes & No & Yes & Yes & [20] \\
\hline SilA, Streptomyces ipomoea & Yes & --- & Yes & Yes & --- & Yes & No & No & Yes & [36] \\
\hline Ssl1, Streptomyces sviceus & Yes & Yes & Yes & Yes & --- & --- & No & No & --- & {$[21]$} \\
\hline SCLAC, Streptomyces sp. & Yes & Yes & Yes & Yes & Yes & --- & --- & Yes & Yes & [37] \\
\hline
\end{tabular}

Abbreviations: ABTS, 2,2'-azino-bis(3-ethylbenzothiazoline-6-sulphonic acid); EDTA, ethylenediamine tetraacetic acid; DMP, 2,6-dimethoxy-phenol; DOPA, dihydroxyphenylalanine; ---, no available data.

- cosmetics: hair dye production, dermatological preparations for skin lightening, deodorants, toothpaste, mouthwash, detergent, soap, and diapers;

- bioremediation: degradation of phenolic compounds in wastewaters from olive oil, cellulose factories or food industry; decontamination of soils containing polycyclic aromatic carbohydrates or pesticides; dye bleaching of textile effluents; reduction of odor from garbage disposal sites; and, strikingly, microbial polyethylene and polystyrene degradation, a capacity attributed to LMCO of very few organisms, including the actinobacterium Rhodococcus ruber [49]-[51].

Until recently, commercial products based on LMCO were available only for food, paper and textile industries, due to the high cost of production, which impedes a broader application of this enzyme [52].

Each specific industrial application requires LMCO with specific properties, concerning optimum $\mathrm{pH}$, temperature, resistance to metal inhibition, etc. For instance, wine stabilization occurs in an acid sulphite-rich environment, and therefore, stability in acid medium and reversible inhibition by sulphite are well desired properties for LMCO used in this process [53]. On the other hand, addition of LMCO to washing powders, decolourization of waste waters, or treatment of kraft pulps require enzymes with high activity at alkaline conditions [21]. Industrial processes may present such extreme conditions; thermostable enzymes are commonly more resistant to chemical denaturation, alkalinity or extreme acidity [54], and bacterial LMCO have proven to be more resistant than the average LMCO found in fungi [55]. In the last decades, although it has been reported thermotolerant LMCO in bacteria [35] [39] [56] they have not been industrially-explored.

The LMCO currently used by industries were obtained from fungi [52]. Some filamentous fungi secrete high amounts of LMCO into the medium, however, uncontrolled growth may also lead to an accumulation of polysaccharides or production of proteases that interfere in the LMCO yield [57]. Also, fungal LMCO generally present more acidic optimum $\mathrm{pH}$ when compared to bacterial enzymes [11] [24], whereas most of LMCO applications require activity in alkaline conditions [21]. Alkaline-tolerant LMCO have been found in bacteria [58] and many actinobacteria (Table 1).

Thus, the current LMCO biotechnological scenario urges for robust enzymes ( $\mathrm{pH}$ and temperature tolerant) in high-yield producers. Obtaining such systems would render economic and more healthy or environment-friendly products, and bacteria seem to be a reliable alternative to overcome problems usually observed in LMCO from fungi.

Strikingly, all LMCO characterized from actinomycetes present one or more desirable properties for industrial application, although, up to date, they have been tested mainly for degradation of dyes used by textile industry. LMCO from S. coelicolor rapidly decolourised the common blue jeans dye Indigo carmine with syringaldehyde as mediator: over $85 \%$ decolourisation occurred within 20 minutes incubation at $45^{\circ} \mathrm{C}$ [39]. Similarly, SCLAC, from Streptomyces sp., efficiently decolourized Indigo carmine and Diamond Black PV in presence of syringal- 
dehyde [37]; dye Orange II was $90 \%$ degraded after $4 \mathrm{~h}$ of incubation with the LMCO produced by S. ipomoea [36]. S. psammoticus LMCO was tested against 10 different dyes, but was effective only for RBBR (Remazol Brilliant Blue R) [59]. The only enzyme tested for pulp and paper industry was produced by S. cyaneus; this LMCO delignified kraft pulp in the presence of the mediator ABTS [19].

\section{Catalytic Properties}

\subsection{Responses of Actinomycetes LMCO to Common Inhibitors}

Ethylenediamine tetraacetic acid (EDTA) is a common LMCO inhibitor. Among characterized actinobacterial LMCO, EDTA inhibited SilA (S. ipomoea), but not SLAC (S. coelicolor) (Table 2). LMCO are also affected by metal ions, e.g. $\mathrm{Ca}, \mathrm{Mn}, \mathrm{Co}, \mathrm{Cu}, \mathrm{Fe}, \mathrm{Zn}, \mathrm{Mg}, \mathrm{Ni}, \mathrm{Hg}$, but the profiles of inhibition or activation are very variable among enzymes. For example, Fe inhibited SilA and S. cyaneus LMCO, Cu inhibited SilA and activated S. cyaneus, Zn inhibited S. cyaneus, whereas S. psammoticus LMCO was activated by all of these ions (Table 2). Furthermore, S. cyaneus CECT 3335 enzyme had $75.7 \%$ of its activity hindered by cinnamic acid. Sodium azide is considered as the only true LMCO inhibitor [60]. However, SLAC, SilA and Ssl1 (S. sviceus) did not present the typical complete inhibition in presence of $1 \mathrm{mM}$ sodium azide: instead, SLAC was not affected at all at this concentration, SilA presented only $40 \%$ activity inhibition even at $10 \mathrm{mM}$ sodium azide, whereas Ssl1 presented only $5 \%$ inhibition at $10 \mathrm{mM}$. An interesting observation concerning this resistance to sodium azide is that all of the three enzymes are 2-domains LMCO (Table 1 and Table 2). Notwithstanding, although only few studies were performed, the obtained data strongly indicate the potential of actinobacterial LMCO for industrial purposes and raise the possibility that these enzymes may overcome fungal LMCO in industrial suitability.

\subsection{LMCO and Ligninolytic Enzymes}

LMCO, lignin peroxidase (LiP, E.C. 1.11.1.14) and manganese peroxidase (MnP, E.C. 1.11.1.13) are the three main ligninolytic enzymes. Unlike LMCO, MnP and LiP are heme-containing enzymes that use $\mathrm{H}_{2} \mathrm{O}_{2}$ as electron acceptor [61].

Some substances have long been cited as "specific laccase substrates", such as syringaldazine [34] [60] [62], or "model laccase substrates", such as guaiacol, 2,2'-azino-bis(3-ethylbenzothiazoline-6-sulphonic acid) (ABTS), 2,6-dimethoxyphenol (DMP), dihydroxyphenylalanine (DOPA) and catechol. Notably, concerning actinomycetes, syringaldazine is not a substrate for all LMCO: EpoA (S. griseus) does not oxidize it, while SLAC (S. cyaneus) exhibited very low affinity (Table 2). A consensus in oxidation was only obtained for the substrates ABTS and DOPA, but they still have to be tested for some of the enzymes. Both syringaldazine and ABTS can be oxidized by the ligninolytic enzymes $\mathrm{MnP}$ or LiP in presence of $\mathrm{H}_{2} \mathrm{O}_{2}$. Fortunately, the $\mathrm{H}_{2} \mathrm{O}_{2}$-dependent oxidation permits the differentiation between that enzymes and LMCO. Ahmad et al. (2011) tested oxidation of syringaldazine and ABTS in presence or absence of $\mathrm{H}_{2} \mathrm{O}_{2}$ to support the conclusion that the protein DypB from the actinobacterium Rhodococcus jostii RHA1 is a LiP [63]. LMCO can also be distinguished from MnP by an assay with the stain leucoberbelin blue, which specifically reacts with Mn compounds released by MnP and produces a blue color that absorbs at $620 \mathrm{~nm}$ [64]. Among characterized actinobacterial LMCO, this test was performed only for EpoA, from S. griseus, but has proved to be useful in determining classification of protein CotA, from Bacillus subtilis [65]. A third class of peroxidase that performs both MnP and LiP functions was discovered in Pleurotus eryngii and named versatile peroxidase [66]. Versatile peroxidases were not found in Bacteria so far.

Other steps are necessary in order to biochemically classify the enzyme, as tyrosine oxidation test and inhibition tests. Both LMCO and tyrosinases oxidize DOPA (dihydroxyphenylalanine), but only tyrosinases oxidize tyrosine to DOPA [9]. Then, tyrosine oxidation assay is often included in characterization studies. An exception to this pattern is the multipotent polyphenol oxidase from the melanogenic marine Alteromonas sp., which presents catalytic capabilities of both tyrosinases and LMCO [67].

However, as it is common that LMCO from actinomycetes are only biochemically-assayed, without gene sequencing, we have suggested a sequence of substrate tests for help in confirmation of which ligninolytic enzyme is present in extract, or if more than one is present. The flow chart (Figure 2) was built based on characterized actinomycetes LMCO (Table 2); besides the ligninolytic enzymes, we have included tyrosinase, a MCO, for its overlap with LMCO in DOPA oxidation. However, it seems likely that a similar scheme would be possible for distinguishing LMCO from other MCO as more proteins are isolated and characterized. 


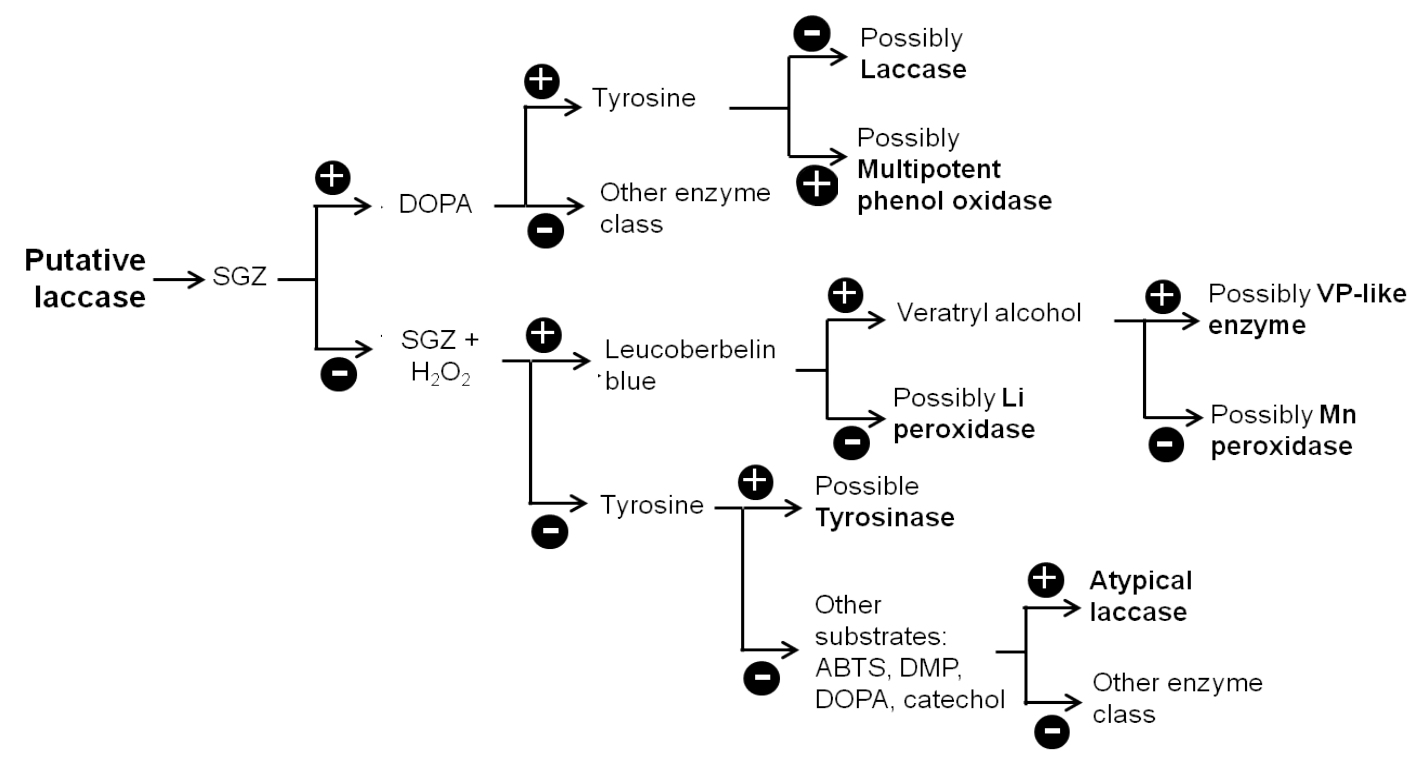

Figure 2. Suggested flow chart for differentiation of laccase and other ligninolytic enzymes. Plus (+) signals indicate positive reaction (e.g., colored reaction in leucoberbelin blue test; or higher enzyme activity in presence of $\mathrm{H}_{2} \mathrm{O}_{2}$, compared to in its absence); minus (-) signals indicate negative result (e.g., non-oxidation of tyrosine; or no higher activity in presence of $\mathrm{H}_{2} \mathrm{O}_{2}$ ). Abbreviations: $\mathrm{Li}$, lignin; Mn, magnesium; SGZ, syringaldazine; ABTS, 2,2'-azino-bis (3-ethylbenzothiazoline-6-sulphonic acid); DMP, 2,6-dimethoxyphenol; DOPA, dihydroxyphenylalanine; VP, versatile peroxidase. Further assays can be performed after identification of the "possible enzyme", as affinity tests for common substrates and inhibitors.

\section{Multigene LMCO Families}

Fungal and plant LMCO genes occur as multigene families. For example, the fungus Pleurotus ostreatus harbors up to 12 LMCO genes [68] whereas Coprinopsis cinerea [69] and the plant model Arabidopsis thaliana, 17 genes [70]. Furthermore, the number of LMCO fungal genes seems to be linked to microbial lifestyle, as saprophytes (wide range of substrates) contain up to 8 genes per species, whereas mycorrhizal fungi (receives plant sugars) contain 1 to 3 per species [71]. Different isozymes develop different physiological roles and have different physico-chemical and catalytic characteristics within a single species [5]. The isoenzymes can be expressed in different growth stages, some are expressed in the initial colonization of the substrate, others in fruiting body formation [12].

In Bacteria, the existence of more than one LMCO gene per genome is rare and only recently multiple LMCO genes were found in the same organism. For instance, Ausec et al. [44] demonstrated that 252 out of 807 microorganisms were found to have more than one LMCO gene, located in chromosomes and/or in plasmids. Among Actinobacteria, 7 genes were detected in Rhodococcus erythropolis; 5 genes in Rhodococcus opacus and Rhodococcus jostii; 4 genes in Arthrobacter sp. FB24 and Arthrobacter aurescens TC1, and 3 genes in Nocardia farcinica IFM10152. One single gene was found only within the genus Mycobacterium.

Considering that multigene families have not been deeply studied in bacteria, so far, information on gene arrangement or coordinated expression is still to be investigated. As many physiological roles are currently assigned to bacterial LMCO proteins: pigmentation, oxidation of phenolic compounds, sporulation, UV and $\mathrm{H}_{2} \mathrm{O}_{2}$ resistance, $\mathrm{Cu}^{2+}$ resistance, efflux, and morphogenesis [16], it can be expected that the occurrence of multigene families may also contribute to the ecological importance and physiology of this group.

\section{LMCO Classification into Superfamilies}

\subsection{LccED}

In 2011, a database was built as a tool for a systematic sequence-based classification and analysis of the multicopper oxidase protein family_LccED (Laccase and Multicopper Oxidase Engineering Database) [72]. The classification was based on 10 protein superfamilies (namely from A to J) formerly distinguished by Hoegger et 
al. [73] based on DNA sequence similarity; and one more superfamily, K, was established for two-domain bacterial LMCO based on SLAC sequence from Streptomyces coelicolor [35]. So far, superfamily K is composed exclusively by Actinobacteria members, and contains the genera Isoptericola, Saccharomonospora, and Streptomyces, although there are evidences that other bacterial groups may also contain two-domains LMCO [44].

Besides superfamily K, actinobacterial LMCO enzymes are also found in superfamilies B, I and J. The characterized LMCO from Actinobacteria with available nucleotide sequences are classified into superfamilies I and K (Figure 3). All two-domain LMCO clustered together, as expected.

\subsection{Primers for Detection of Bacterial LMCO Genes}

Few primers for detection of bacterial LMCO genes can be found in literature. All of them were designed based on copper-binding regions (cbr), which have the same aminoacidic residues conserved in both bacterial and fungal LMCO. The oligonucleotide primer Cu2R [71] was first designed for detection of cbrII from basidiomycetes LMCO. Cu1AF primer [74] aligns to the sequence that codifies the two histidines from cbrI, and was designed by using sequences from diverse bacterial taxa (including Actinobacteria) as source; it presents a high degeneracy level (6 out of 20 bases) in order to detect LMCO genes in a variety of bacterial groups. Used together, the primers have shown specificity for bacterial LMCO genes, as they proved to be unable to amplify LMCO genes from DNA of basidiomycetes or ascomycetes [74].

Recently, another primer (Cu4R) was designed using the cbrIV region of three-domain LMCO sequences from five bacterial genera, including Streptomyces [75]. Along with Cu1AF, positive amplifications from many bacterial genera were obtained.

In our laboratory, we have for the first time designed primers for specific amplification of actinomycetes LMCO belonging to the LccED superfamilies I and K (unpublished). The designed primers have amplified LMCO fragments from actinobacteria isolates that were undetected by the above mentioned primers and the obtained fragments were correctly assigned to the predicted superfamily.

\section{Cellular Location of Bacterial LMCO}

Nowadays, fungal LMCO are considered to be extracellular enzymes [43], whereas bacterial LMCO are still assumed to be intracellular or spore-bound [16] [76]. However, this idea has long been contested, since Alexandre and Zhulin (2000), showed the presence of signal peptides in bacterial LMCO sequences. More recently, it has been revealed that $76 \%$ of 1200 putative genes for LMCO enzymes possessed signal peptides [44] which indicated an extracellular destination and corroborated the previous study. Currently, it is known [55] that both fungal and bacterial LMCO may be intracellular [77] [78] as well as extracellular [44] [59].

\section{Conclusion}

The phylum Actinobacteria is recognized by its intrinsic capacity to produce unconventional and biotechnologically important molecules for the most diverse sectors of industry. Currently, thousands of LMCO from Actinobacteria have been putatively assigned by molecular techniques, but only a few have been characterized. The

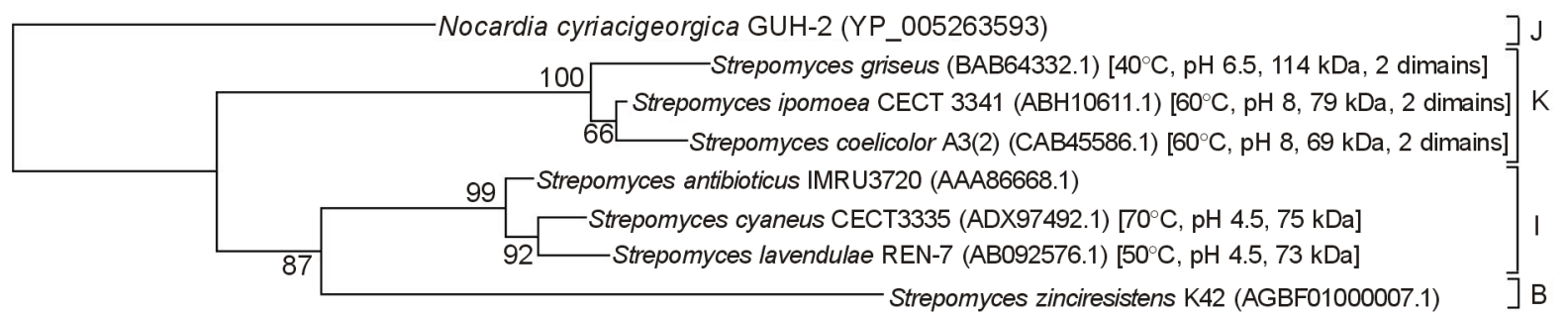

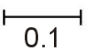

Figure 3. Neighbour-joining tree based on laccase gene sequences showing relationships among laccase superfamilies (according to The Laccase and Multicopper Oxidase Engineering Database-LccED). Only superfamilies containing actinobacteria laccases were used (indicated by letters B, I, J and K). Numbers at nodes are percentage bootstrap values based on 1000 resampled datasets. Bar, 0.1 substitution per nucleotide position. 
striking characteristics observed in these examples are not commonly found among fungal isolates, and reveal a huge potential within the enzymes from the bacterial phylum. All of the characterized LMCO presented some of the robust properties important for industrial application, i.e., tolerance to high temperature, salt concentration, alkalinity/acidity and/or pH variation. The LMCO potential for industrial application is notoriously diverse, and the unusual properties of actinobacterial LMCO must be taken into account in order to strengthen efforts in its prospection and characterization. Nowadays, all LMCO used commercially are obtained from fungi, with many drawbacks related to the producer characteristics. Exploring actinobacterial LMCO may circumvent limitations and may make the processes more profitable, efficient and applicable to more industrial fields.

\section{References}

[1] Claus, H. (2004) Laccases: Structure, Reactions, Distribution. Micron, 35, 93-96. http://dx.doi.org/10.1016/j.micron.2003.10.029

[2] Yoshida, H. (1883) Chemistry of Lacquer (Urushi) Part 1. Journal of the Chemical Society, 43, 472-486. http://dx.doi.org/10.1039/ct8834300472

[3] Bertrand, G. (1896) Sur la presence simultanee de la laccase et de la tyrosinase dans le suc de quelques champignons. Comptes rendus hebdomadaires des séances de l'Académie des sciences, 123, 463-465.

[4] Givaudan, A., Effosse, A., Faure, D., Potier, P., Bouillant, M. and Bally, R. (1993) Polyphenol Oxidase from Apospirillum lipoferum Isolated from the Rhizosphere: Evidence for a Laccase in Non-Motile Strains of Azospirillum lipoferum. FEMS Microbiology Letters, 108, 205-210. http://dx.doi.org/10.1111/j.1574-6968.1993.tb06100.x

[5] Piscitelli, A., Pezzella, C., Giardina, P., Faraco, V. and Giovanni, S. (2010) Heterologous Laccase Production and Its Role in Industrial Applications. Bioengineered Bugs, 1, 252-262.

[6] Bugg, T.D.H., Ahmad, M., Hardiman, E.M. and Sing, R. (2011) The Emerging Role for Bacteria in Lignin Degradation and Bio-Product Formation. Current Opinion in Biotechnology, 22, 394-400. http://dx.doi.org/10.1016/j.copbio.2010.10.009

[7] Strong, P.J. and Claus, H. (2011) Laccase: A Review of Its Past and Its Future in Bioremediation. Critical Reviews in Environmental Science and Technology, 41, 373-434. http://dx.doi.org/10.1080/10643380902945706

[8] Bourbonnais, R. and Paice, M.G. (1990) Oxidation of Non-Phenolic Substrates-An Expanded Role for Laccase in Lignin Biodegradation. FEBS Letters, 267, 99-102. http://dx.doi.org/10.1016/0014-5793(90)80298-W

[9] Thurston, C.F. (1994) The Structure and Function of Fungal Laccases. Microbiology, 1, 19-26. http://dx.doi.org/10.1099/13500872-140-1-19

[10] Gianfreda, L., Xu, F. and Bollag, J. (1999) Laccases: A Useful Group of Oxidoreductive Enzymes. Bioremediation Journal, 3, 1-26. http://dx.doi.org/10.1080/10889869991219163

[11] Baldrian, P. (2005) Fungal Laccases-Occurrence and Properties. FEMS Microbiology Reviews, 30, $215-242$. http://dx.doi.org/10.1111/j.1574-4976.2005.00010.x

[12] Giardina, P., Faraco, V., Pezzella, C., Piscitelli, A., Vanhulle, S. and Sannia, G. (2010) Laccases: A Never-Ending Story. Cellular and Molecular Life Sciences, 67, 369-385. http://dx.doi.org/10.1007/s00018-009-0169-1

[13] Galli, C., Gentili, P. and Jolivalt, C. (2011) How Is the Reactivity of Laccase Affected by Single-Point Mutations? Engineering Laccase for Improved Activity towards Sterically Demanding Substrates. Applied Microbiology and Biotechnology, 91, 123-131. http://dx.doi.org/10.1007/s00253-011-3240-4

[14] Janusz, G., Kucharzyk, K.H., Pawlik, A., Staszczak, M. and Paszczynski, A.J. (2013) Fungal Laccase, Manganese Peroxidase and Lignin Peroxidase: Gene Expression and Regulation. Enzyme and Microbial Technology, 52, 1-12. http://dx.doi.org/10.1016/j.enzmictec.2012.10.003

[15] Claus, H. (2003) Laccases and Their Occurrence in Prokaryotes. Archives of Microbiology, 179, 145-150.

[16] Sharma, P., Goel, R. and Capalash, N. (2006) Bacterial Laccases. World Journal of Microbiology and Biotechnology, 23, 823-832. http://dx.doi.org/10.1007/s11274-006-9305-3

[17] Ball, A.S., Betts, W.B. and McCarthy, A.J. (1989) Degradation of Lignin-Related Compounds by Actinomycetes. Applied and Environmental Microbiology, 55, 1642-1644.

[18] Kirby, R. (2005) Actinomycetes and Lignin Degradation. Advances in Applied Microbiology, 58, 125-168. http://dx.doi.org/10.1016/S0065-2164(05)58004-3

[19] Arias, M.E., Arenas, M., Rodríguez, J., Soliveri, J., Ball, A.S. and Hernández, M. (2003) Kraft Pulp Biobleaching and Mediated Oxidation of a Nonphenolic Substrate by Laccase from Streptomyces cyaneus CECT 3335. Applied and Environmental Microbiology, 69, 1953-1958. http://dx.doi.org/10.1128/AEM.69.4.1953-1958.2003

[20] Niladevi, K.N., Jacob, N. and Prema, P. (2008) Evidence for a Halotolerant-Alkaline Laccase in Streptomyces psam- 
moticus: Purification and Characterization. Process Biochemistry, 43, 654-660. http://dx.doi.org/10.1016/j.procbio.2008.02.002

[21] Gunne, M. and Urlacher, V.B. (2012) Characterization of the Alkaline Laccase Ssl1 from Streptomyces sviceus with Unusual Properties Discovered by Genome Mining. PloS ONE, 7, 1-8.

[22] Kumar, S.V., Phale, P.S., Durani, S. and Wangikar, P.P. (2003) Combined Sequence and Structure Analysis of the Fungal Laccase Family. Biotechnology and Bioengineering, 83, 386-394. http://dx.doi.org/10.1002/bit.10681

[23] Sakurai, T. and Kataoka, K. (2007) Basic and Applied Features of Multicopper Oxidases, CueO, Bilirubin Oxidase, and Laccase. The Chemical Record, 7, 220-229. http://dx.doi.org/10.1002/tcr.20125

[24] Reiss, R., Ihssen, J., Richter, M., Eichhorn, E., Schilling, B. and Thöny-Meyer, L. (2013) Laccase versus Laccase-Like Multi-Copper Oxidase: A Comparative Study of Similar Enzymes with Diverse Substrate Spectra. PLoS ONE, 8, e65633. http://dx.doi.org/10.1371/journal.pone.0065633

[25] Whitman, W.B., Goodfellow, M., Kämpfer, P., Busse, H.J., Trujillo, M.E., Ludwig, W. and Suzuki, K.I. (2012) Bergey’s Manual of Systematic Bacteriology: The Actinobacteria. Springer Publishing Company, New York.

[26] Goodfellow, M. and Williams, S.T. (1983) Ecology of Actinomycetes. Annual Review of Microbiology, 37, $189-216$. http://dx.doi.org/10.1146/annurev.mi.37.100183.001201

[27] Lee, J. (1997) Biological Conversion of Lignocellulosic Biomass to Ethanol. Journal of Biotechnology, 56, 1-24. http://dx.doi.org/10.1016/S0168-1656(97)00073-4

[28] Godden, B., Ball, A.S., Helvenstein, P., McCarthy, A.J. and Penninckx, M. (1992) Towards Elucidation of the Lignin Degradation Pathway in Actinomycetes. Microbiology, 138, 2441-2448. http://dx.doi.org/10.1099/00221287-138-11-2441

[29] Taylor, C.R., Hardiman, E.M., Ahmad, M., Sainsbury, P.D., Norris, P.R. and Bugg, T.D.H. (2012) Isolation of Bacterial Strains Able to Metabolize Lignin from Screening of Environmental Samples. Journal of Applied Microbiology, 113, 521-530. http://dx.doi.org/10.1111/j.1365-2672.2012.05352.x

[30] Bérdy, J. (2005) Bioactive Microbial Metabolites. The Journal of Antibiotics, 58, 1-26. http://dx.doi.org/10.1038/ja.2005.1

[31] Goodfellow, M. and Fiedler, H.P. (2010) A Guide to Successful Bioprospecting: Informed by Actinobacterial Systematic. Antonie van Leeuwenhoek, 98, 119-142. http://dx.doi.org/10.1007/s10482-010-9460-2

[32] Prakash, D., Nawani, N., Prakash, M., Bodas, M., Mandal, A., Khetmalas, M. and Kapadnis, B. (2013) Actinomycetes: A Repertory of Green Catalysts with a Potential Revenue Resource. BioMed Research International, 2013, Article ID: 264020. http://dx.doi.org/10.1155/2013/264020

[33] Endo, K., Hayashi, Y., Hibi, T., Hosono, K., Beppu, T. and Ueda, K. (2003) Enzymological Characterization of EpoA, a Laccase-Like Phenol Oxidase Produced by Streptomyces griseus. The Journal of Biochemistry, 133, 671-677. http://dx.doi.org/10.1093/jb/mvg086

[34] Suzuki, T., Endo, K., Ito, M., Tsujibo, H., Miyamoto, K. and Inamori, Y. (2003) A Thermostable Laccase from Streptomyces lavendulae REN-7: Purification, Characterization, Nucleotide Sequence, and Expression. Bioscience Biotechnology and Biochemistry, 67, 2167-2175. http://dx.doi.org/10.1271/bbb.67.2167

[35] Machczynski, M.C., Vijgenboom, E., Samyn, B. and Canters, G.W. (2004) Characterization of SLAC: A Small Laccase from Streptomyces coelicolor with Unprecedented Activity. Protein Science, 13, 2388-2397. http://dx.doi.org/10.1110/ps.04759104

[36] Molina-Guijarro, J.M., Pérez, J., Muñoz-Dorado, J., Guillén, F., Moya, R., Hernández, M. and Arias, M.E. (2009) Detoxification of Azo Dyes by a Novel pH-Versatile, Salt-Resistant Laccase from Streptomyces ipomoea. International Microbiology, 12, 13-21.

[37] Lu, L., Zeng, G., Fan, C., Ren, X., Wang, C., Zhao, Q., Zhang, J., Chen, M., Chen, A. and Jiang, M. (2013) Characterization of a Laccase-Like Multicopper Oxidase from Newly Isolated Streptomyces sp. C1 in Agricultural Waste Compost and Enzymatic Decolorization of Azo Dyes. Biochemical Engineering Journal, 72, 70-76. http://dx.doi.org/10.1016/j.bej.2013.01.004

[38] Fernandes, T.A.R., Silveira, W.B., Passos, F.M.L. and Zucchi, T.D. (2013) Characterization of a Thermotolerant Laccase Produced by Streptomyces sp. SBo86. Annals of Microbiology, Published Online. http://dx.doi.org/10.1007/s13213-013-0781-z

[39] Dubé, E., Shareck, F., Hurtubise, Y., Daneault, C. and Beauregard, M. (2008) Homologous Cloning, Expression, and Characterisation of a Laccase from Streptomyces coelicolor and Enzymatic Decolourisation of an Indigo Dye. Applied Microbiology and Biotechnology, 79, 597-603. http://dx.doi.org/10.1007/s00253-008-1475-5

[40] Skálová, T., Dohnálek, J., Østergaard, L.H., Østergaard, P.R., Kolenko, P., Dusková, J., Štěpánková, A. and Hašek, J. (2009) The Structure of the Small Laccase from Streptomyces coelicolor Reveals a Link between Laccases and Nitrite 
Reductases. Journal of Molecular Biology, 385, 1165-1178. http://dx.doi.org/10.1016/j.jmb.2008.11.024

[41] Alexandre, G. and Zhulin, I.B. (2000) Laccases are Widespread in Bacteria. Trends in Biotechnology, 18, 41-42. http://dx.doi.org/10.1016/j.jmb.2008.11.024

[42] Hakulinen, N., Kiiskinen, L.L., Kruus, K., Saloheimo, M., Paananen, A., Koivula, A. and Rouvinen, J. (2002) Crystal Structure of a Laccase from Melanocarpus albomyces with an Intact Trinuclear Copper Site. Nature Structural Biology, 9, 601-605.

[43] Valderrama, B., Oliver, P., Medrano-Soto, A. and Vazquez-Duhalt, R. (2003) Evolutionary and Structural Diversity of Fungal Laccases. Antonie van Leeuwenhoek, 84, 289-299. http://dx.doi.org/10.1016/j.jmb.2008.11.024

[44] Ausec, L., Zakrzewski, M., Goesmann, A., Schlüter, A. and Mandic-Mulec, I. (2011) Bioinformatic Analysis Reveals High Diversity of Bacterial Genes for Laccase-Like Enzymes. PLoS ONE, 7, e25724 http://dx.doi.org/10.1371/journal.pone.0025724

[45] Couto, S.R. and Herrera, T. (2006) Industrial and Biotechnological Applications of Laccases: A Review. Biotechnology Advances, 24, 500-513. http://dx.doi.org/10.1016/j.biotechadv.2006.04.003

[46] Kunamneni, A., Plou, F.J., Ballesteros, A. and Alcalde, M. (2008) Laccases and Their Applications: A Patent Review. Recent Patents on Biotechnology, 2, 10-24. http://dx.doi.org/10.2174/187220808783330965

[47] Widsten, P. and Kandelbauer, A. (2008) Laccase Applications in the Forest Products Industry: A Review. Enzyme and Microbial Technology, 42, 293-307. http://dx.doi.org/10.1016/j.enzmictec.2007.12.003

[48] Shraddha, R.S., Sehgal, S., Kamthania, M. and Kumar, A. (2011) Laccase: Microbial Sources, Production, Purification, and Potential Biotechnological Applications. Enzyme Research, 2011, Article ID: 217861.

[49] Orr, I.G., Hadar, Y. and Sivan, A. (2004) Colonization, Biofilm Formation and Biodegradation of Polyethylene by a Strain of Rhodococcus ruber. Applied Microbiology and Biotechnology, 65, 97-104.

[50] Sivan, A., Szanto, M. and Pavlov, V. (2006) Biofilm Development of the Polyethylene-Degrading Bacterium Rhodococcus ruber. Applied Microbiology and Biotechnology, 72, 346-352. http://dx.doi.org/10.1007/s00253-005-0259-4

[51] Mor, R. and Sivan, A. (2008) Biofilm Formation and Partial Biodegradation of Polystyrene by the Actinomycete Rhodococcus ruber. Biodegradation, 19, 851-858. http://dx.doi.org/10.1007/s10532-008-9188-0

[52] Osma, J.F., Toca-Herrera, J.L. and Rodríguez-Couto, S. (2010) Uses of Laccases in the Food Industry. Enzyme Research, 2010, Article ID: 918761. http://dx.doi.org/10.4061/2010/918761

[53] Madhavi, V. and Lele, S.S. (2009) Laccase: Properties and Applications. Bioresources, 4, 1694-1717.

[54] Haki, G.D. and Rakshit, S.K. (2003) Developments in Industrially Important Thermostable Enzymes: A Review. Bioresource Technology, 89, 17-34. http://dx.doi.org/10.1016/S0960-8524(03)00033-6

[55] Hildén, K., Hakala, T.K. and Lundell, T. (2009) Thermotolerant and Thermostable Laccases. Biotechnology Letters, 31, 1117-1128. http://dx.doi.org/10.1007/s10529-009-9998-0

[56] Miyazaki, K. (2005) A Hyperthermophilic Laccase from Thermus thermophilus $\mathrm{HB}_{27}$. Extremophiles, 9, 415-425. http://dx.doi.org/10.1007/s00792-005-0458-z

[57] Couto, S.R. and Toca-Herrera, J.L. (2007) Laccase Production at Reactor Scale by Filamentous Fungi. Biotechnology Advances, 25, 558-569. http://dx.doi.org/10.1016/j.biotechadv.2007.07.002

[58] Li, Y., Zuo, W., Li, Y. and Wang, X. (2012) Cloning of Multicopper Oxidase Gene from Ochrobactrum sp. 531 and Characterization of Its Alkaline Laccase Activity towards Phenolic Substrates. Advances in Biological Chemistry, 2, 248-255. http://dx.doi.org/10.4236/abc.2012.23031

[59] Niladevi, K.N. and Prema, P. (2008) Effect of Inducers and Process Parameters on Laccase Production by Streptomyces psammoticus and Its Application in Dye Decolourization. Bioresource Technology, 99, 4583-4589. http://dx.doi.org/10.1016/j.biortech.2007.06.056

[60] Johannes, C. and Majcherczyk, A. (2000) Laccase Activity Tests and Laccase Inhibitors. Journal of Biotechnology, 78, 193-199. http://dx.doi.org/10.1016/S0168-1656(00)00208-X

[61] Ruiz-Dueñas, F.J. and Martínez, Á.T. (2009) Microbial Degradation of Lignin: How a Bulky Recalcitrant Polymer Is Efficiently Recycled in Nature and How We Can Take Advantage of This. Microbial Biotechnology, 2, 164-177. http://dx.doi.org/10.1111/j.1751-7915.2008.00078.x

[62] Harkin, J.M. and Obst, J.R. (1993) Syringaldazine, an Effective Reagent for Detecting Laccase and Peroxidase in Fungi. Experientia, 29, 381-387. http://dx.doi.org/10.1007/BF01926734

[63] Ahmad, M., Roberts, J.N., Hardiman, E.M., Singh, R., Eltis, L.D. and Bugg, T.D.H. (2011) Identification of DypB from Rhodococcus jostii RHA1 as a Lignin Peroxidase. Biochemistry, 50, 5096-5107. http://dx.doi.org/10.1021/bi101892z 
[64] Anderson, C.R., Johnson, H.A., Caputo, N., Davis, R.E., Torpey, J.W. and Tebo, B.M. (2009) Mn(II) Oxidation Is Catalyzed by Heme Peroxidases in “Aurantimonas manganoxydans” Strain SI85-9A1 and Erythrobacter sp. Strain SD-21. Applied and Environmental Microbiology, 75, 4130-4138. http://dx.doi.org/10.1128/AEM.02890-08

[65] Hullo, M.F., Moszer, I., Danchin, A. and Martin-Verstraete, I. (2001) CotA of Bacillus subtilis Is a Copper-Dependent Laccase. Journal of Bacteriology, 183, 5426-5430. http://dx.doi.org/10.1128/JB.183.18.5426-5430.2001

[66] Camarero, S., Sarkar, S., Ruiz-Dueñas, F.J., Martínez, M.J. and Martínez, A.T. (1999) Description of a Versatile Peroxidase Involved in the Natural Degradation of Lignin That Has Both Manganese Substrate Interaction Sites Description of a Versatile Peroxidase Involved in the Natural Degradation of Lignin That Has Both Manganese Peroxidase. The Journal of Biological Chemistry, 274, 10324-10330.

[67] Sanchez-Amat, A. and Solano, F. (1997) A Pluripotent Polyphenol Oxidase from the Melanogenic Marine Alteromonas sp. Shares Catalytic Capabilities of Tyrosinases and Laccases. Biochemical and Biophysical Research Communications, 240, 787-792. http://dx.doi.org/10.1006/bbrc.1997.7748

[68] Castanera, R., Pérez, G., Omarini, A., Alfaro, M., Pisabarro, A.G., Faraco, V., Amore, A. and Ramírez, L. (2012) Transcriptional and Enzymatic Profiling of Pleurotus ostreatus Laccase Genes in Submerged and Solid-State Fermentation Cultures. Applied and Environmental Microbiology, 78, 4037-4045. http://dx.doi.org/10.1128/AEM.07880-11

[69] Kilaru, S., Hoegger, P.J. and Kües, U. (2006) The Laccase Multi-Gene Family in Coprinopsis cinerea Has Seventeen Different Members That Divide into Two Distinct Subfamilies. Current Genetics, 50, 45-60. http://dx.doi.org/10.1007/s00294-006-0074-1

[70] McCaig, B.C., Meagher, R.B. and Dean, J.F.D. (2005) Gene Structure and Molecular Analysis of the Laccase-Like Multicopper Oxidase (LMCO) Gene Family in Arabidopsis thaliana. Planta, 221, 619-636. http://dx.doi.org/10.1007/s00425-004-1472-6

[71] Luis, P., Walther, G., Kellner, H., Martin, F. and Buscot, F. (2004) Diversity of Laccase Genes from Basidiomycetes in a Forest Soil. Soil Biology and Biochemistry, 36, 1025-1036. http://dx.doi.org/10.1016/j.soilbio.2004.02.017

[72] Sirim, D., Wagner, F., Wang, L., Schmid, R.D. and Pleiss, J. (2011) The Laccase Engineering Database: A Classification and Analysis System for Laccases and Related Multicopper Oxidases. Database, 2011, Article ID: bar006. http://dx.doi.org/10.1093/database/bar006

[73] Hoegger, P.J., Kilaru, S., James, T.Y., Thacker, J.R. and Kües, U. (2006) Phylogenetic Comparison and Classification of Laccase and Related Multicopper Oxidase Protein Sequences. FEBS Journal, 273, 2308-2326. http://dx.doi.org/10.1111/j.1742-4658.2006.05247.x

[74] Kellner, H., Luis, P., Zimdars, B., Kiesel, B. and Buscot, F. (2008) Diversity of Bacterial Laccase-Like Multicopper Oxidase Genes in Forest and Grassland Cambisoil Soil Samples. Soil Biology \& Biochemistry, 40, 638-648. http://dx.doi.org/10.1016/j.soilbio.2007.09.013

[75] Ausec, L., van Elsas, J.D. and Mandic-Mulec, I. (2011) Two- and Three-Domain Bacterial Laccase-Like Genes Are Present in Drained Peat Soils. Soil Biology and Biochemistry, 43, 975-983. http://dx.doi.org/10.1016/j.soilbio.2011.01.013

[76] Dwivedi, U.N., Singh, P., Pandey, V.P. and Kumar, A. (2011) Structure-Function Relationship among Bacterial, Fungal and Plant Laccases. Journal of Molecular Catalysis B: Enzymatic, 68, 117-128. http://dx.doi.org/10.1016/j.molcatb.2010.11.002

[77] Schlosser, D., Fritsche, W. and Grey, R. (1997) Patterns of Ligninolytic Enzymes in Trametes versicolor. Distribution of Extra- and Intracellular Enzyme Activities during Cultivation on Glucose, Wheat Straw and Beech Wood. Applied and Environmental Microbiology, 47, 412-418.

[78] Diamantidis, G., Aline, E., Bally, R. and Potier, P. (2000) Purification and Characterization of the First Bacterial Laccase in the Rhizospheric Bacterium Azospirillum lipoferum. Soil, 32, 919-927.

\section{Abbreviations}

MCO: Multicopper Oxidase

LMCO: Laccase-Like Multicopper Oxidase 